\title{
How is the Student's Negotiation Text in Collaborative Learning of Flipped Classroom and a CyberLink Power Director Media Apps
}

\author{
Cahyo Hasanudin ${ }^{1 *}$, Ayu Fitrianingsih ${ }^{2}$, Kundharu Saddhono ${ }^{3}$ \\ ${ }^{1}$ Indonesian Language and Literature Education Department, IKIP PGRI Bojonegoro, Bojonegoro 62114, Indonesia \\ ${ }^{2}$ English Education Department IKIP PGRI Bojonegoro, Bojonegoro 62114, Indonesia \\ ${ }^{3}$ Universitas Sebelas Maret Surakarta, Surakarta 57126, Indonesia
}

Corresponding Author Email: cahyo.hasanudin@ikippgribojonegoro.ac.id

https://doi.org/10.18280/isi.240601

Received: 26 June 2019

Accepted: 10 September 2019

Keywords:

negotiation text, flipped classroom,

CyberLink power director apps

\begin{abstract}
This article aims to investigate the form of negotiation texts written by tenth grade students of Accounting Class in SMK PGRI 2 Bojonegoro, Indonesia. This qualitative research uses a case study approach. The research instruments are test questions, interview guidelines, and observation guidelines. The data are collected by using the methods of tests, interviews, and observations. It is validated using triangulations of data, researcher, and theory. Then, it is analysed using content analysis method. The results of this research indicate that the structure of negotiation texts created by students is in line with the statement of the Ministry of Education and Culture. The impacts of the results give a broader concept that flipped classroom is very appropriate to teach the millennial generations. They are able to learn negotiation text easily through teaching materials that have been uploaded in youtube using a CyberLink Power Director media apps.
\end{abstract}

\section{INTRODUCTION}

In Indonesia, negotiation text is taught to the tenth grade students using 2013 curriculum on basic competencies of $3.10,3.11,4.10$, and 4.11 . The students are taught with a problem that involves other parties. These parties negotiate each other to determine a solution. Through this negotiation, a problem will be easily resolved. The form of solving a problem can be reviewed from the success of a negotiation. Students who learn to negotiate through negotiation text can foster mutual respect between them, build social sensitivity, and understand various social interactions. This research tries to reveal the negotiation text that is taught in flipped classroom, in which the videos are made by using CyberLink Power Director media apps.

Negotiation text is a form of social interaction which can be found in form of dialogues (drama) [1,2], a combination of narration and dialogue, offering letter, and demand for goods. In learning negotiation text, students have to adjust the language used to make other people understand it [3]. Negotiation text develops a deeper understanding of the actual law involved in the conflict and introduces students to a set of life skills [4].

These skills lead students to be competent in negotiating and writing negotiation text [5]. Success in negotiating can be caused by several factors, namely, 1) the willingness to compromise with other people, 2) no one is disadvantaged, 3) the agreement is practical to be done, 4) the reasons given are able to influence other people. Whereas negotiation will be ended in four ways, namely, there is no agreement, victory for one party, compromise, and integrative [6]. Engestrøm [7] states that successful negotiation tends to change disputes, not only achieve instrumental goal. Students are able to negotiate; it does not depend on their writing skills [8].
The ability to write negotiation text can be seen from the success of students in making the structure of it based on their ideas. The structure of negotiation text between the seller and buyer starts from the orientation [9], demand, fulfillment, offer, agreement, purchase, and closing. The structure of negotiation text between employee and employer starts from the orientation, submission, offer, agreement, and closing [10]. The language features of negotiation text are declarative/statement, interrogative/question, imperative/command, wishes, conditional sentences, and many used of causative conjunctions [11].

Both of these abilities are very useful for students as new knowledge and experience. When they face with the real life, they are able to convey ideas, refute, and convice opinions by using good language [12, 13].

Based on the observations, the tenth grade students of Accounting Class in SMK PGRI 2 Bojonegoro, Indonesia have low ability in writing negotiation text. There are only a few of them that pass the criteria of minimum score. Based on the result of interview with one of students, he says that writing negotiation text is a boring and difficult learning. In line with a study shows that students are less active in constructing negotiation text [14]. In addition, teacher is lack of preparation in delivering materials, giving less guidance, and evaluating the learning process.

This problem finds a solution by implementing flipped classroom. It is first introduced Bergmann and Sams [15] as the basic of the most recent class literature. This method flips the assignment and the materials provided to make students are able to get it in the outside of the class. In the classroom, they discuss the assignments. Huang [16] emphasizes that students' preparation before the class begins is very important for them because they can be more involved in the learning process and achieve more satisfying learning 
outcomes. The results of a study [17] reveals that flipped classroom has a positive effect on students' skill, involvement, and knowledge. Simon [18] says that knowledge has a role in the formation of behavior. This method is able to help students be relax in gaining information and learning complex issues, such as creativity and critical thinking $[19,20]$.

The syntax of flipped classroom requires teacher to create learning media that can be accessed easily by students, it can be in form of videos. Flipped classroom [21] requires technology in form of networks, applications, and videos. Making the video becomes a weakness in implementing flipped classroom. It can be triggered by teacher's low ability in mastering technology. It makes him difficult to create videos and upload it. Teacher takes a long time to compile video materials [22]. Sometimes, videos, that have been created, are not interesting the students [23].

To make students be interested in learning, teacher has to create short and interesting videos. Kurniadi et al. [24] introduces various applications that can be used for video editing via smartphones and recommends an application that is quite easy, namely Power Director. This application is a software made by Cyber Link that can be downloaded via an android smartphone that utilizes CUDA for video transcoding $[25,26]$. This application is very professional in editing videos because the navigation is easy to be used and the video conversion is very fast. Through the CyberLink Power Director, teacher can design a learning video that attracts students' attention continuously [27]. This application is easily operated even without internet network connection [28].

The display of CyberLink PowerDirector application can be seen in Figure 1.

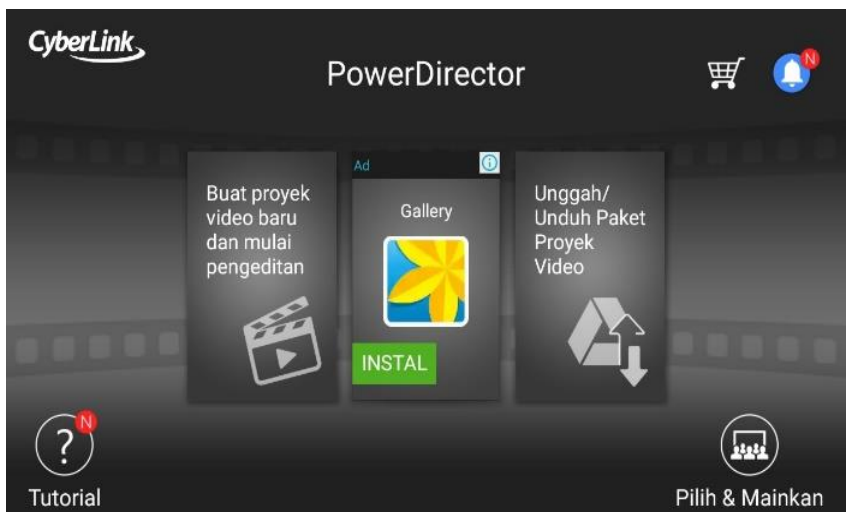

Figure 1. The homepage of CyberLink PowerDirector Apps

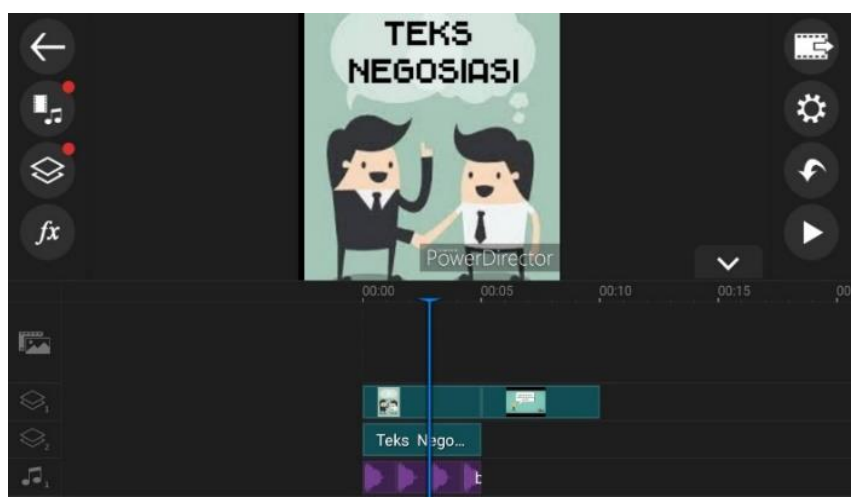

Figure 2. The Initial scheme of negotiation text material
The researchers began to compose the material of negotiation text using CyberLink Power Director apps via smartphone. This material contains a description of negotiation text, the structure of text, the examples of negotiating and writing negotiation text. The initial scheme of negotiation text can be seen in Figure 2.

The material that has been successfully created through CyberLink Power Director can be stored. The storage menu on the CyberLink Power Director apps can be: saved to the gallery or SD card, shared on Facebook or YouTube, export project to the CyberLink cloud. The researchers choose to store on YouTube because it syncs directly to Youtube and reduces the amount of memory usage in smartphone internal storage. The storage step can be seen in Figure 3.

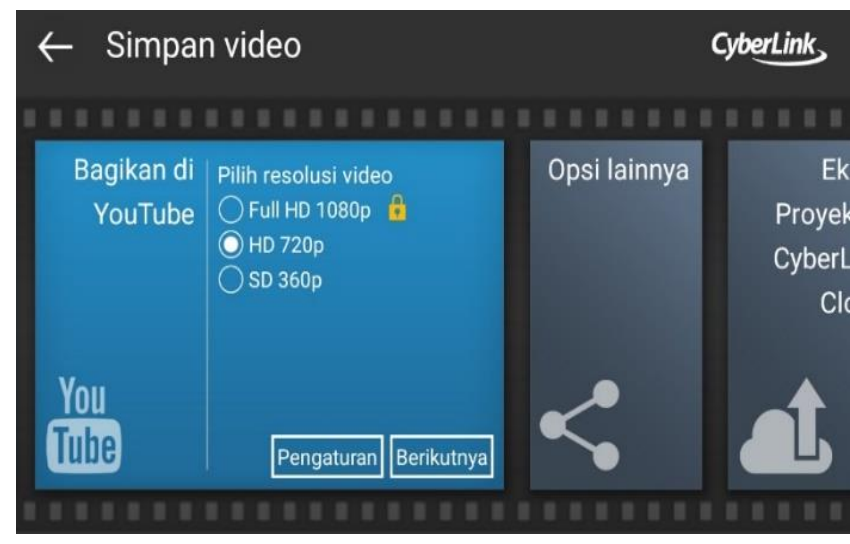

Figure 3. Share files on YouTube

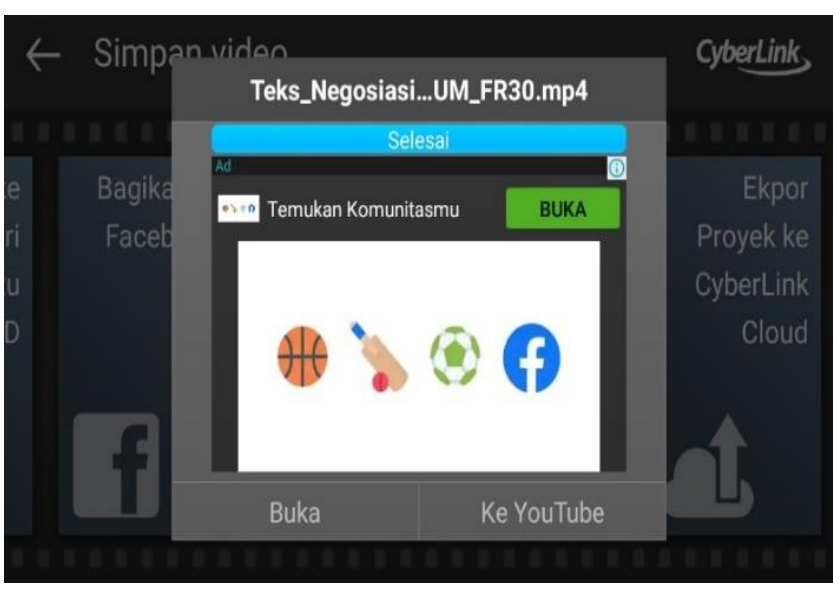

Figure 4. The material is ready to be shared on YouTube

The result of study by Az-zahra [29] shows that Power Director apps can be used in producing a combined video into MPEG-4 format to make song animation media. This application is used by Chen and Yeh [30] to convert all image files, animations, and video clips into MPG format. The trainer used Power Director Software to edit or produce videos for students [31].

The finished video is then uploaded to the YouTube page so students can easily access it. This ease is part of flipped classroom learning. It provides space for students to be able to access the videos and learn the materials about negotiation text anywhere and anytime. They can make a list of questions about negotiation text that can be asked to their friends or teacher when the class begins. In this learning, it requires students to be able to think creatively inside and outside the classroom. Creative thinking is always needed in everything, 
especially in solving problems given by the teacher/lecturer [32].

Based on the explanation above, the researchers are eager to investigate how is the student's negotiation text in collaborative learning of flipped classroom and a CyberLink Power Director media apps. This collaborative learning is very helpful for students to understand negotiation text. For instance, the ease of accessing materials. The students are able to learn the materials about negotiation text repeatedly, observe the concepts or procedures of good negotiating, and write negotiation text. This material is very important to be taught because the concept of negotiation is always present in daily life. Therefore, the students have to be equipped earlier with a comprehensive understanding about this material.

This article is divided into some parts to make it clear to the readers, the first is introduction in which the researcher introduce the background of study, the second is research methodology, the third is the research instrument. The fourth part explains about the techniques in collecting the data, the fifth is data validation technique, the sixth is data analysis technique, the next is results and discussion, and the last part is the conclusion of this study.

\section{RESEARCH METHODOLOGY}

This study was qualitative research using a case study approach. Case study is understood as a case of social phenomena using research question 'How' [33, 34]. According to Yin in Burga and Rezania [35] case study does not require propositions specifically. But it needs broad directions to guide a research [36] in information-oriented sampling. The information obtained in this study is how is the form of negotiation text (orientation, demand, fulfillment, offer, agreement, purchase, closing) written by the tenth grade students of Accounting class in SMK PGRI 2 Bojonegoro, Indonesia when they are taught by implementing flipped classroom learning using CyberLink Power Director media apps.

\subsection{Research time and place}

This study was conducted in the even semester at Tenth Grade of Accounting 2 SMK PGRI 2 Bojonegoro, Indonesia.

\subsection{Research subject}

The participants in this study were 29 students. It consisted of 7 male students and 22 female students. They were chosen because the school had implemented 2013 Curriculum. From 29 students, the researcher took 7 students to be interviewed because they had the ability to negotiate, write negotiation text, and communicate well.

\section{RESEARCH INSTRUMENT}

The instruments of this study were the researcher, but they still used additional instrument such as test questions, interview guidelines, and observation guidelines. The test questions were used to measure students' skill in composing negotiation text based on its structure (orientation, demand, fulfillment, offer, agreement, purchase, closing). The interview guidelines were used to interview students to clarify their answers of the test questions. The observation guidelines were used to observe students' activities in flipped classroom learning with CyberLink Power Director apps.

\section{DATA COLLECTION TECHNIQUES}

The techniques in collecting data were done by giving test, interviewing the subjects, and observing the learning process.

\subsection{Test method}

Test method was used as a basis for knowing the students' abilities in understanding negotiation text. The result of it was as a benchmark of students' skill in composing negotiation text. The test was in form of essay test about the writing skill of orientation, demand, fulfillment, offer, agreement, purchase, and closing in negotiation text. The essay test was arranged by the researchers by involving Indonesian language teachers at SMK PGRI 2 BojonegoroIndonesia, and the lecturers of Indonesian Language and Literature Education Department at IKIP PGRI BojonegoroIndonesia as the expert consultants and validators. The validated test could be tested for research subjects. The test contained only one question because it had already represented all elements of negotiation text. The steps in collecting data through test method were 1) preparing test questions, 2) distributing it to all participants, 3) supervising students in giving answer, 4) correcting, 5) analysing test results.

\subsection{Interview}

The unstructured interview was conducted by giving openended questions, and recorded the results [37]. It was done without using systematic and complete guidelines. The questions were open, so it could be answered by the subjects. The answers were always recorded by the researchers as the materials in validating data. These three steps were carried out because the researchers wanted to explore the subjects' views about the ability in creating negotiation text. Therefore, the seven subjects were examined as the informants. In-depth interview was conducted to obtain more detailed and honest data.

\subsection{Observation}

The observation was done to know the real condition of the research subjects. This observation produced a broader view about the problem studied. This study used direct observation method by observing the implementation of flipped classroom learning inside and outside the classroom, and monitoring students to ensure that they had accessed the video URL in YouTube.

\section{DATA VALIDATION TECHNIQUES}

The data validation was carried out by using triangulation techniques. There are four types of triangulation [38], namely triangulations of data, researcher, method, and theory. Joslin and Müller [39] suggested to use representativeness and variety sampling. The researchers used triangulations of data, researcher, and theory. In data triangulation, researchers 
compared the results of test and results of interview. Then, the researchers rechecked and compared it with the theories of negotiation text. In researcher triangulation, the researchers utilized the existences of the first and second researchers to know their data was reliable. Both researchers were used to reduce the inaccuracies in collecting data. In theory triangulation, the researchers used national and international books, and also the articles of national and international journals as a form of data validation. In this triangulation, the researchers ensure that the findings in this study were a new finding that had the innovation in the use of method and learning media.

\section{DATA ANALYSIS TECHNIQUES}

Data analysis technique in this study was content-analysis method. Content analysis developed inductive coding schemes through data analysis that enabled the researchers to take stock of existing knowledge bases in a systematic manner $[4,41]$, so that researchers were very careful to limit their conclusions [42]. According to Miles and Huberman [43] content analysis method consisted of three activities that run simultaneously, namely 1) data reduction, 2) data presentation, and 3) drawing conclusions/verification.

\subsection{Data reduction}

The researchers recorded 29 data about the results of students' answers in very detailed descriptions. The data was analyzed to be simplified into the data that contained the structure of negotiation text (orientation, demand, fulfillment, offer, agreement, purchase, closing) so the researchers assumed that the data was truly in accordance with the indicators.

\subsection{Data presentation}

The researchers found 7 of 30 data that had been reduced showed that the negotiation text was in accordance with the indicators. These seven data were arranged in detailed to make it easily understood. It was analyzed to obtain the descriptions of each indicator of negotiation text structure.

\subsection{Drawing conclusion/verification}

The researchers made preliminary conclusions that were temporary about the negotiation text written by students. It was verified by interviewing 7 students who made negotiation text based on the structure of it and the ways in negotiating. If the results of interview are the same as the results of test, the researchers will be able to make a credible final conclusion. It will become the final conclusion of this study.

\section{RESULTS AND DISCUSSION}

One of the videos that had been created could be downloaded in https://www.youtube.com/watch? $=\mathrm{vLAqUjz}$ KE8\& $\mathrm{t}=73 \mathrm{~s}$. It could be seen in Figure 5.

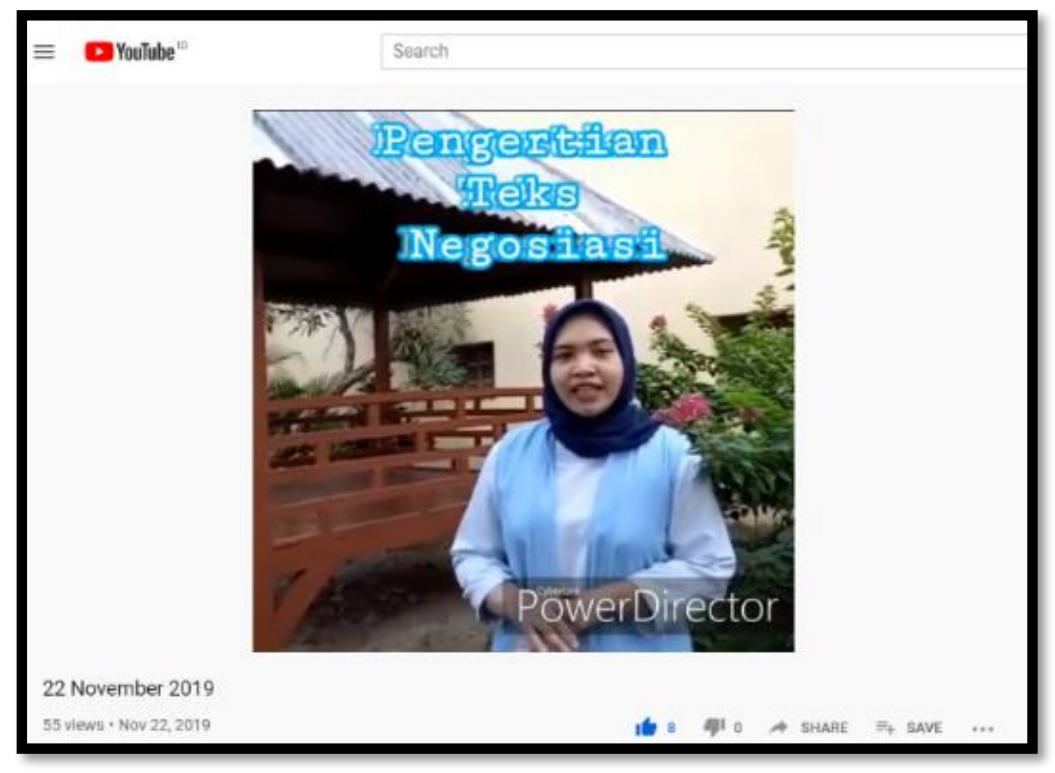

Figure 5. The display of negotiation text material in YouTube

The videos from CyberLink Power Director apps are very useful in supporting the implementation of flipped classroom learning in delivering negotiation text material. The results of students writing can be shown as follows.

\subsection{Results}

Based on the structure of negotiation text that is initiated by the Ministry of Education and Culture, the followings are the structure of negotiation text written by students for
Indonesian language subject. The first structure is orientation. The form of it in negotiation text is as shown in Figure 6.

On the answer sheet, students made orientation by displaying the representatives of the company and labor. It contained the filling of company wage complaints. Based on their answers, it was known that students were able to arrange orientation according to the guidelines of negotiation text. When the researchers asked, why he answered like that, he explained that the concept appeared in his mind when he saw the problem. This could be shown in the following 
interview transcript.

P : "Apakah kamu sudah melihat video yang sudah diungah, Nak?" [have you seen the uploaded video,dear?]

S1 : "Sudah, Pak!'”YYes, Sir!]

P : "Kamu sudah paham konten orientasi pada teks negosiasi?" [have you understood the orientation content in negotiation text?]

S1 : "Sudah." [ I have]

$\mathrm{P}$ : "Mengapa saudara mengangkat wakil perusahaan dan wakil buruh sebagai tokoh percakapan?" [Why do you take the representatives of company and labor as the characters in conversation?]

P : "Karena topik percakapan antara kedua pihak tersebut bisa disusun menjadi teks negosiasi yang baik, mampu sebagai pembuka teks negosiasi sehingga menhasilkan sebuah persetujuan" [because the topic between them can be arranged into a good negotiation text, it is able to be orientation in negotiation text to produce an agreement]

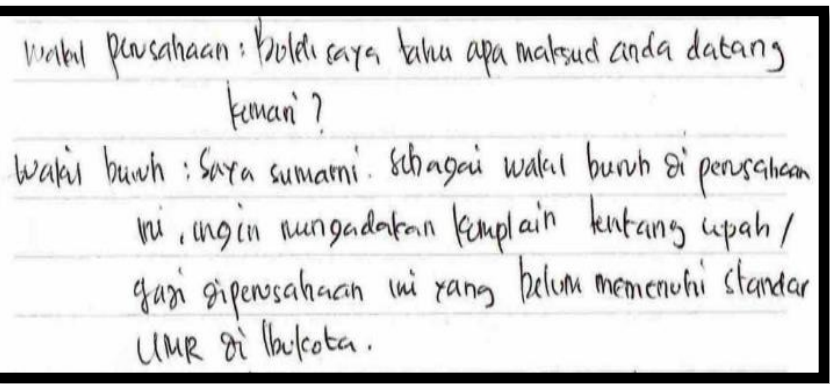

Figure 6. The orientation on negotiation text

The second structure is demand. It was written by students in negotiation text as shown in Figure 7.

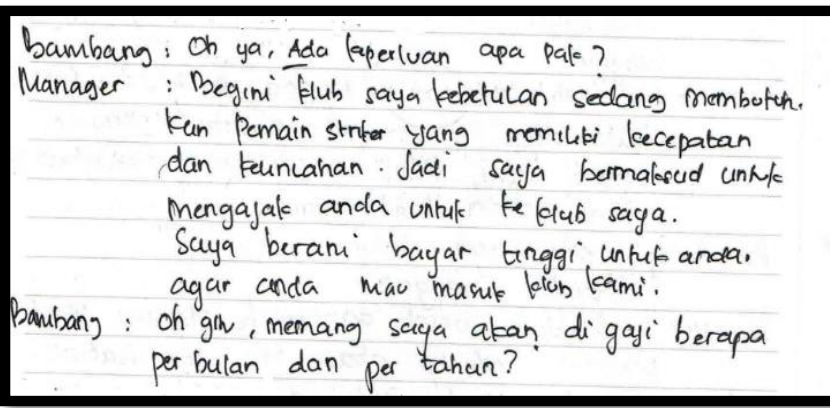

Figure 7. The demand in negotiation text

On this answer sheet, student made a demand by involving the character 'Bambang' and the manager. The manager looked for a new football player, he gave a demand to 'Bambang'. In this part, student had been able to make proper and correct structure of negotiation text. The researchers interviewed the student, why he wrote it, he answered that the form of demand could be seen from one of parties giving an offer. It could be seen in the following interview transcript.

$\mathrm{P} \quad$ : "Kamu sudah memahami struktur teks negosiasi?" [Have you understood the structure of negotiation text?]
S2 : "Sudah."[yes, I have]

$\mathrm{P}$ : "Mengapa saudara membuat permintaan dengan melibatkan tokoh dan manager?" [why do you make a demand by involving the character and the manager?]

S2 : "Karena kondisi seperti ini, sering saya lihat pada sinetron sehingga saya mampu membuat teks negosiasi pada bagian permintaan." [Because I have often watched it on films so I can make the negotiation text in demand section]

The third structure was fulfillment. It was written by students and could be seen in Figure 8 .

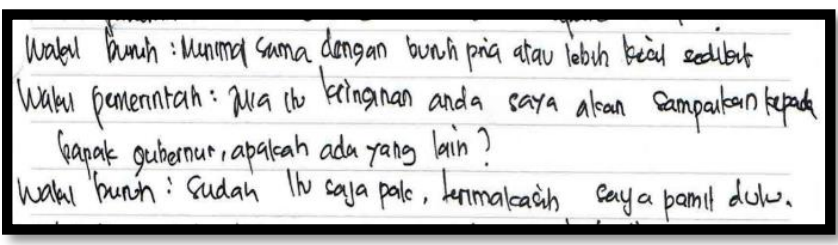

Figure 8. Fulfillment in negotiation text

On this answer sheet, student made fulfillment by involving the representatives of labor and the government. The government gave a fulfillment toward the labor's wishes. The conversation created a fulfillment in negotiation text. When the researchers asked student, why she wrote the fulfillment by involving the representatives of labor and government. She answered that she often saw this condition in television. The interview transcript could be seen as follows.

P : "Kamu sudah memahami bagian pemenuhan pada teks negosiasi?'[have you understood the fulfillment part of negotiation text]

S3 : "Sudah. Pak"[I have, Sir!]

$\mathrm{P}$ : "Mengapa saudara membuat pemenuhan dengan melibatkan wakil buruh dan wakil pemerintah?" [Why do you make a fulfillment by involving the representatives of labor and government?]

S3 : "Karena kondisi seperti ini, sering saya lihat berita di televisi." [because I have often seen the news likes this condition on television]

The fourth structure is offer. The offer written by student on her answer sheet can be seen in Figure 9.

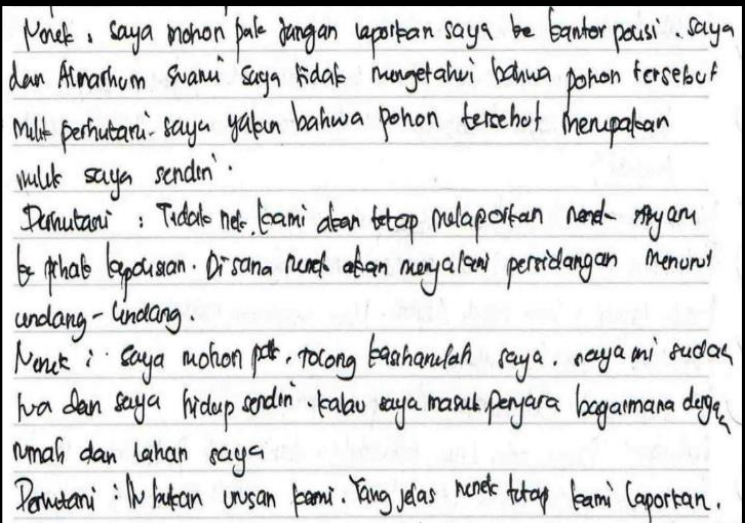

Figure 9. The offer part in negotiation text 
On this answer sheet, the offer in negotiation text written by students was adapted to a case between old lady and Perhutani. The old lady asked an offer to Perhutani not to be reported her to the police because of wood theft case. When the researchers asked her, why she wrote it by involving these two characters, she answered that she had ever heard this case from her friend. It could be seen from the following interview transcript.

$\mathrm{P} \quad$ : "Mengapa kamu menulis bagian penawaran dengan melibatkan tokoh nenek dengan perhutani?" [Why do you write the offer part by involving the old lady and Perhutani?]

S4 : "Karena saya pernah mendengar kasus ini dari teman saya, jadi saya membuat teks negosiasi pada bagian penawaran dengan melibatkan dua tokoh yang salah satu tokohnya memberikan penawaran." [Because I have ever heard this case from my friend, so I make it in offer part by involving the two characters in which one of them give an offer]

The fifth structure is agreement. The form of this part is written by students as shown in Figure 10.

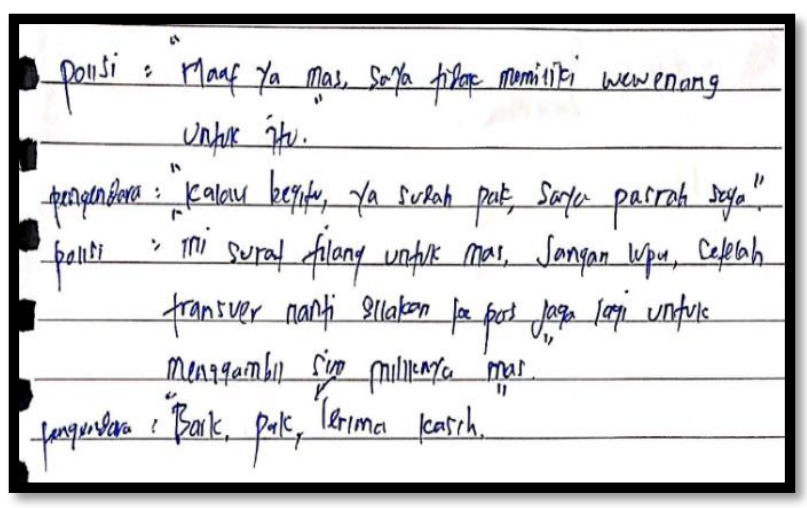

Figure 10. The agreement part in negotiation text

On this answer sheet, student wrote an answer that involving the police and a motor rider in negotiation text. When the researcher asked him, why he wrote it, he answered that he had ever broken the rule and he ever wanted to give money to the police but the police refused it. Based on this true story and the examples uploaded in YouTube, the student was able to write good negotiation text, especially in agreement part. It can be seen in the following interview transcript.

P : “Kamu sering ditilang?" [Do you often get ticketed?]

S4 : "Tidak, Pak. Baru sekali" [No, Sir! Just once]

$\mathrm{P} \quad$ : "Mengapa kamu menulis teks negosiasi seolaholah kamu sering ditilang?" [ why do you write negotiation text as if you were often ticketed?]

S4 : "Saya hanya ditilang sekali, dan pada waktu itu, saya mencoba berdamai dengan polisi dengan memberikan uang sogok, namun polisi itu menolaknya." [I just get ticketed once, and that time I try to make an agreement with the police by giving money, but the police refuses it.]

P : "Betul, itu tindakan yang salah." [Good, that's a wrong thing]

S4 : "Iya Pak, saya tahu. Oleh karena itu, berawal dari pengalaman inilah dan materi yang sudah diunggah oleh bapak, saya bisa menulis teks negosiasi dengan baik." [ I know sir. That's why from this experience and the material uploaded, I can write negotiation text well]

P : "Kamu paham pada bagian persetujuan yang kamu tulis?" [do you understand the agreement part that you write?]

S4 : "Ya, saya paham, di sana saya menulis bahwa saya setuju untuk mengikuti aturan yang berlaku, tidak menggunakan cara sendiri." [ yes, I do. I write that I agree to follow the rules, not using my own way]

The sixth structure is purchase. It can be seen in Figure 11.

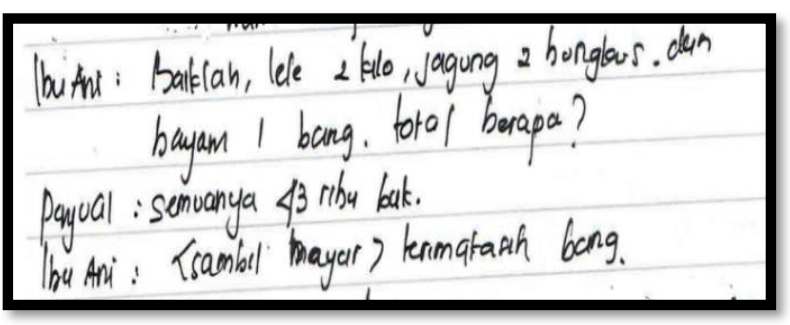

Figure 11. Purchase part in negotiation text

On this answer sheet, student wrote the purchase part in negotiation text by involving the characters of Ibu Ani (the buyer) and the seller. Both characters negotiated to make a purchase. So the seller made a deal with the price requested by the buyer. When the researchers asked student, why she involved both characters in purchase part, she answered that she often followed her mom to the market so she knew the process of purchasing the price that had been offered. It can be seen in the following interview transcript.

P : "Kamu pernah melakukan negosiasi?" [Have you ever done a negotiation?]

S6 : "Belum, Pak." [not yet,Sir!]

$\mathrm{P}$ : "Mengapa kamu bisa menulis bentuk pembelian pada teks negosiasi?" [why do you able to write the purchase part in negotiation text?]

S6 : "Setiap libur sekolah saya ikut ibu ke pasar, saya selalu mengamati ibu melakukan negosiasi dengan penjual. Berdasar apa yang saya amati inilah, saya bisa menulis bentuk pembelian pada teks negosiasi." [every holiday I go to market with my mom. I always observe that my mom is negotiating with the seller. Based on my observation, I can write the purchase part in negotiation text]

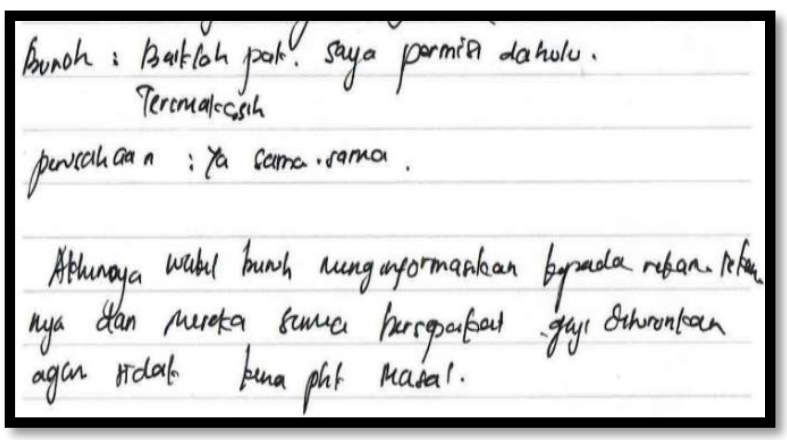

Figure 12. The closing part in negotiation text 
The seventh structure is closing. The closing in negotiation text is the final part in negotiation text structure. The closing part written by student can be seen in Figure 12.

On this answer sheet, student wrote a closing in negotiation text by involving the characters of labor and employer. She made a closing based on the previous part of negotiation. The problem in closing part had been negotiated so both parties accepted it. When the researchers asked student, why she wrote it, she answered that she observed the video made by the researchers. On that video she observed carefully the closing part in negotiation text. It could be seen in the following interview transcript.

$\mathrm{P} \quad$ : "Mengapa kamu menulis penutup pada teks negosiasi seperti itu?" [why do you write the closing like that?]

S7 : "Saya mengamati konsep penutup teks negosiasi pada materi yang diunggah pada youtube." [I observe the concept of closing on the material uploaded on YouTube]

P : "Kamu memahaminya?" [do you understand it?]

S7 : "Ya, saya paham, sehingga saya membuat penutup pada teks negosiasi berdasarkan materi yang sudah terunggah dengan mengungkap masalah antara buruh dan pengusaha." [yes, I do. So I make a closing in negotiation text based on the material uploaded by revealing a problem between a labor and employer]

\subsection{Discussion}

Referring to the structure of negotiation text that has been revealed by the Ministry of Education and Culture. The structure made by tenth grade students of Accounting class in SMK PGRI 2 Bojonegoro has been in line with it.

In orientation part of negotiation text, students write it based on the concepts in their minds. These concepts involve the representative of labor that want to submit complaints to the Company. The orientation is the opening of persuasive text [44]. It contains the introduction of the author's main idea about a phenomenon that will be discussed.

In the demand part of negotiation text, students are able to write well and correctly. It is written by them to reflect that one of the parties gives an offer. The offer is given by the manager to the new football player. In this part, the first negotiator conveys its intention to the second negotiator that he wants to negotiate [9].

In the fulfillment part of negotiation text, the students write a fulfillment by involving the character of labor that asks for a more decent salary from the government. The form of fulfillment is evidenced by the government that fulfill the labor's wishes. The fulfillment part of negotiation text is presented by the parties for the purpose of collective choice [45].

In the offer part of negotiation text, the students write the offer part based on the case that she has ever seen. The case involved an old lady who asks for an offer to Perhutani. Ardana, et.al [46] state that the bargaining strategies are two, first, distributive, means that the form of negotiation in which the lose-win situation. Second, integrative, means that the form of negotiation in which the win-win situation. The settlement of problems based on humanity and mutual respect [47].
In the agreement part of negotiation text, students write it based on personal experience and then compile it into negotiation text based on the examples uploaded by teacher. The form of this agreement involves a policeman who is ticketing a rider. The rider agrees to what is said by the policeman. In the agreement part, the parties try to make an agreement on a problem that is disputed [48].

In the purchase part of negotiation text, students write it based on their experiences too. The student often goes to the market with her mother so she understands the way in which the mother does. She writes it exactly the same as what her mom said during at the market. The strategic purchasing requires all components of various purchasing functions, includes citizen, buyers, providers, regulators, and government [49].

In the closing part of negotiation text, the students write it by involving the characters of labor and employer who have ended the proses of negotiation. In this part, student explains the agreement between both parties with a gravitation. In this part, the employee and employer say thanks each other and a commitment $[9,50]$.

The abilities of tenth grade students of Accounting class in SMK PGRI 2 Bojonegoro in writing negotiation text are in accordance with the structure of negotiation text. It shows that the collaboration of flipped classroom learning and CyberLink Power Director media apps is very suitable to be implemented to the basic competencies of 3.10, 3.11, 4.10, and 4.11. The implementation of flipped classroom gives innovation in the teaching and learning process, the students are motivated to learn the materials in form of videos [51]. The teacher should make a video about negotiation text by making scenario to illustrate the flow of it and the characters that appear in the video [52]. The materials in form of videos generated from the application use several media namely texts, pictures/images, sounds, and videos media so it activates more than one senses in understanding the materials [53].

\section{CONCLUSION}

The form of negotiation text written by tenth grade students of Accounting class in flipped classroom learning with CyberLink Power Director media apps has already well referred to the negotiation text structure according to the Ministry of Education and Culture. In orientation, students write a dialogue between the representatives of labor and company. In demand part, they write a dialogue between manager and a new football player. In the fulfillment part, they write a dialogue between the representatives of government and labor. In offer part, they write a dialogue between an old lady and Perhutani. In agreement part, they write a dialogue between a policeman and a rider. In purchase part, they write a dialogue between a woman and seller. In closing of negotiation text, they write a dialogue between the representatives of labor and employer. In this part is marked by an agreement between both parties.

Based on the students' negotiation texts, it can be said that flipped classroom model is very appropriate for millennial generation learning. They can easily learn it anywhere and anytime through teaching materials that have been uploaded on YouTube made using the CyberLink Power Director apps. In the classroom, the teacher only gives instructions, guides the discussion, and solves problems that students faced in 


\section{ACKNOWLEDGMENT}

The researchers would like to thank to LPPM of IKIP PGRI Bojoneegoro and LPPM of Sebelas Maret University.

\section{REFERENCES}

[1] Rahman, T. (2018). Teks Dalam Kajian Struktur Dan Kebahasaan. (H. Ibda, ed.). Jawa Tengah, Indonesia: CV Pilar Nusantara.

[2] Tentor, T.S. (2018). Top One Ulangan Harian Sma/Ma IPA Kelas X: Pilihan Cerdas Menjadi Bintang. Jakarta, Indonesia: PT Bintang Wahyu.

[3] Farhan, A., Martha, I.N., Putrayasa, I.B. (2018). Peningkatan kemampuan siswa menulis teks negosiasi dengan menggunakan metode karyawisata kelas $\mathrm{x}$ ipa 1 man 1 buleleng. Jurnal Pendidikan Bahasa Dan Sastra Indonesia Undiksha, 8(2): 223-234. https://doi.org/10.23887/jjpbs.v8i2.20615

[4] Zohar, I. (2015). "The art of negotiation" leadership skills required for negotiation in time of crisis. Procedia - Social and Behavioral Sciences, 209: 540-548. https://doi.org/10.1016/j.sbspro.2015.11.285

[5] Suherli, Suryaman, M., Septiaji, A., Istiqomah. (2017). Bahasa Indonesia: Buku Guru (4th ed.). Jakarta, Indonesia: Kementerian Pendidikan dan Kebudayaan.

[6] Carnevale, P.J., Pruitt, D.G. (1992). Negotiation and mediation. Annual Review of Psychology, 43: 531-582. https://doi.org/10.1146/annurev.ps.43.020192.002531

[7] Helstad, K., Lund, A. (2012). Teachers' talk on students' writing: Negotiating students' texts in interdisciplinary teacher teams. Teaching and Teacher Education, 28(4): 599-608. https://doi.org/10.1016/j.tate.2012.01.004

[8] Goff, B., Rish, R. (2019). What's brought along and brought about: Negotiating writing practices in two high school classrooms. Learning, Culture and Social Interaction, in $\quad$ Press, 13 . https://doi.org/10.1016/j.lcsi.2019.02.016

[9] Kemendikbud. (2013). Buku siswa: Bahasa Indonesia Ekspresi Diri Dan Akademik Untuk Kelas X. Jakarta, Indonesia: Kementerian Pendidikan dan kebudayaan.

[10] Dewi, P.N.S., Suandi, I.N., Yasa, I.N. (2015). Implementasi pembelajaran menulis teks negosiasi berdasarkan kurikulum 2013 di kelas x.b akuntansi SMK Negeri 1 Singaraja. Jurnal Bahasa Dan Sastra Indonesia Undiksha, 3(1): 1-12. http://dx.doi.org/10.23887/jjpbs.v3i1.5058

[11] Kosasih, E. (2014). Jenis-jenis Teks. Bandung, Indonesia: Yrama Widya.

[12] Silvia, L., Hariadi, J., Effendi, D.I. (2019). Kemampuan siswa kelas $\mathrm{x}$ SMA negeri 3 Langsa menulis teks negosiasi. Jurnal Samudra Bahasa, 2(1): 1-8.

[13] Osmimi. (2018). Peningkatan keterampilan menulis teks negosiasi mengunakan model cooperative learning tipe circ kelas $\mathrm{x}$ ips 5 sma negeri 4 bukittinggi. Jurnal AKRAB JUARA, 3(3): 158-165. https://doi.org/10.1017/CBO9781107415324.004

[14] Suryani, S., Untari, T., Nurmiwati, N. (2018). Kemampuan mengkonstruksikan teks negosiasi dengan memperhatikan isi struktur dan kebahasaan pada siswa https://doi.org/10.31764/paedagoria.v9i2.827

[15] Bergmann, J., Sams, A. (2012). Flip your classroom: reach every student in every class every day. Industrial Society for Technology in Education and ASCD.

[16] Hung, H.T. (2015). Flipping the classroom for English language learners to foster active learning. Computer Assisted Language Learning, 28(1): 81-96. https://doi.org/10.1080/09588221.2014.967701

[17] Murillo-Zamorano, L.R., López Sánchez, J.Á., GodoyCaballero, A.L. (2019). How the flipped classroom affects knowledge, skills, and engagement in higher education: Effects on students' satisfaction. Computers and Education, 141: 103608 https://doi.org/10.1016/j.compedu.2019.103608

[18] Retnowati, R., Suharyati, H., Manurung, R.T., Maknun, D., Armariena, D.N., Hetilaniar, H., Hasanudin, C., Murniviyanti, L., Anwar, S., Setyorini, R. (2018). The effect of environmental teaching method and the level of natural intelligence on the environmental view of the students behavior. Journal of Physics: Conference Series, 1114(1): 1-7. https://doi.org/10.1088/17426596/1114/1/012104

[19] Hasanudin, C., Fitrianingsih, A. (2018). Flipped classroom using screencast-o-matic apps in teaching reading skill in indonesian language. International Journal of Pedagogy and Teacher Education, 2: 143-150. https://doi.org/10.20961/ijpte.v2i0.25356

[20] Rodríguez, G., Díez, J., Pérez, N., Baños, J.E., Carrió, M. (2019). Flipped classroom: Fostering creative skills in undergraduate students of health sciences. Thinking Skills and Creativity, 33: 100575. https://doi.org/10.1016/j.tsc.2019.100575

[21] Hasanudin, C., Fitrianingsih, A. (2018). The implementation of flipped classroom using screencasto-matic to improve students' verbal linguistic intelligence. International Journal of Engineering \& Technology, 7(4.15): 435-439. https://doi.org/10.14419/ijet.v7i4.15.23602

[22] Apriyanti, Y., Nyeneng, I.D.P., Suana, W. (2017). Pengembangan perangkat pembelajaran flipped classroom pada materi getaran harmonis. Jurnal Pembelajaran Fisika, 5(2): 69-79.

[23] Milman, B.N. (2012). The flipped classroom strategy: What is it and how can it best used? Journal the Washington University, 9(3): 85-87.

[24] Kurniadi, H., Arif, M., Lucky, N. (2019). Optimalisasi pemanfaatan smartphone sebagai alat sederhana dalam membuat film bagi siswa sma di pekanbaru. Jurnal Pengabdian Masyarakat Multidisiplin, 3(1): 42-47.

[25] Fitria. (2018). Powerdirector, aplikasi edit dan gabungkan video di android yang menarik. Newsth.com, p. $1 . \quad$ Retrieved from https://www.newsth.com/2018/09/13/powerdirectoraplikasi-edit-dan-gabungkan-video-di-android-yangmenarik/.

[26] Blake, G., Dreslinski, R.G., Mudge, T., Flautner, K. (2010). Evolution of thread-level parallelism in desktop applications categories and subject descriptors. ACM SIGARCH Computer Architecture News - ISCA '10, 38(3): 302-313. https://doi.org/10.1145/1816038.1816000

[27] Rajagukguk, W. (2011). Perbedaan minat belajar siswa dengan media komputer program cyberlink power 
director dan tanpa media komputer pada pokok bahasan kubus dan balok di kelas viii smp negeri 1 hamparan perak tahun ajaran 2009/2010. Jurnal Pendidikan Matematika, 5(2): 205-220 https://doi.org/10.22342/jpm.5.2.599

[28] Andarwati, M. (2019). Pembelajaran sejarah kontekstual, kreatif, menyenangkan di kelas dengan "power director" bagi generasi z. Jurnal Pendidikan Sejarah Indonesia, 2(1): 64-81.

[29] Az-zahra, O.W. (2019). Pengembangan pembelajaran teks piwulang serat wulangreh pupuh gambuh dengan media animasi tembang untuk siswa kelas viii smp negeri 1 cilacap. Piwulang Jawi: Journal of Javanese Learning and Teaching, 7(1): 41-46.

[30] Chen, H.H., Yeh, M.L. (2005). A new multimediabased instruction for hip arthroplasty in clinical practice. Computer Methods and Programs in Biomedicine, 80(2): 181-186. https://doi.org/10.1016/j.cmpb.2005.07.005

[31] Liu, S.H., Tsai, H.C., Huang, Y.T. (2015). Collaborative professional development of mentor teachers and pre-service teachers in relation to technology integration. Educational Technology and Society, 18(3): 161-172.

[32] Saddhono, K., Hasanudin, C., Fitrianingsih, A. (2019). The ability to think creatively on SSCS using schoology Apps, how is the student's language metacognitive awareness? Ingenierie des Systemes d'Information, 24(4): 367-375. https://doi.org/10.18280/isi.240402

[33] Kaidesoja, T. (2019). Building middle-range theories from case studies. Studies in History and Philosophy of Science, 78: 23-31. https://doi.org/10.1016/j.shpsa.2018.11.008

[34] Mok, K.Y., Shen, G.Q., Yang, R.J., Li, C.Z. (2017). Investigating key challenges in major public engineering projects by a network-theory based analysis of stakeholder concerns: A case study. International Journal of Project Management, 35(1): 78-94. https://doi.org/10.1016/j.ijproman.2016.10.017

[35] Burga, R., Rezania, D. (2017). Project accountability: An exploratory case study using actor-network theory. International Journal of Project Management, 35(6): 1024-1036. https://doi.org/10.1016/j.ijproman.2017.05.001

[36] Flyvbjerg, B. (2006). Five misunderstandings about case-study research. Qual. Inq, 12(2): 219-245. https://doi.org/10.1177/1077800405284363

[37] Creswell, J.W. (1998). Qualitative Inquiry and Research Design: Choosing Among Five Traditions. London: Sage Publications, Inc.

[38] Denzin, N.K. (1970). The Research act: A theoretical introduction to sociological methods. New York, USA: McGraw Hill.

[39] Joslin, R., Müller, R. (2016). Identifying interesting project phenomena using philosophical and methodological triangulation. International Journal of Project Management, 34(6): 1043-1056. https://doi.org/10.1016/j.ijproman.2016.05.005

[40] Drisko, J.W., Maschi, T. (2016). Content Analysis. New York: xford University Press.

[41] Gaur, A., Kumar, M. (2018). A systematic approach to conducting review studies: An assessment of content analysis in 25 years of IB research. Journal of World Business, 53(2): 280-289. https://doi.org/10.1016/j.jwb.2017.11.003

[42] Neuendorf, K.A. (2002). The Content Analysis: Guidebook. Thousand Oaks: Sage Publications.

[43] Miles, M.B., Huberman, A.M. (2007). Analisis Data Kualitatif: Buku Sumber Tentang Metode-Metode Baru. Jakarta: Universitas Indonesia Press.

[44] Setiyono, H. (2014). Pendalaman Buku Teks Bahasa Indonesia 1 SMA Kelas $\mathrm{x}$. Jakarta, Indonesia: Yudhistira.

[45] Zartman, I.W. (2007). Negotiation and Conflict Management: Essays on Theory and Practice. Routledge: Taylor \& Francis Group. https://doi.org/10.4324/9780203945254

[46] Ardana, K., Mujiati, N.W., Sriathi, A.A.A. (2009). Perilaku Keorganisasian. Yogyakarta, Indonesia: Graha Ilmu.

[47] Sutrisno, \& Ruswandi, K. (2007). Modul Melakukan Negosiasi Bisnis Dan Manajemen. Sukabumi, Indonesia: Yudhistira.

[48] Nolan-Haley, J.M. (1992). Alternative Dispute Resolution in a Nutshell. New York, USA: West Publishing Company.

[49] Klasa, K., Greer, S.L., van Ginneken, E. (2018). Strategic purchasing in practice: Comparing ten European countries. Health Policy, 122(5): 457-472. https://doi.org/10.1016/j.healthpol.2018.01.014

[50] Peeling, N. (2009). Negosiasi Juara. Jakarta, Indonesia: Esensi.

[51] Hasanudin, C., Fitrianigsih, A. (2019). Analisis gaya belajar mahasiswa pada pembelajaran flipped classroom Jurnal Pendidikan Edutama, 6(1): 31-36. https://doi.org/10.30734/jpe.v6i1.364

[52] Dewi, P.N.S., Suandi, I.N., Yasa, I.N. (2015). Implementasi pembelajaran menulis teks negosiasi berdasarkan kurikulum 2013 di kelas x.b akuntansi smk negeri 1 singaraja. Jurnal Bahasa Dan Sastra Indonesia Undiksha, $3(1)$ : 1-12. http://dx.doi.org/10.23887/jjpbs.v3i1.5058

[53] Sugiarto, M.A. (2017). Pengembangan media video Number Heads Together (NHT) untuk tenaga pengajar di TK Labschool IKIP development of video media Number Heads Together (NHT) for teachers at kinder Labschool. Journal of Early Childhood and Inclusive Education, 1(1): 49-63. 